\title{
ANALISIS FAKTOR YANG MEMENGARUHI ADVERSITY QUOTIENT PERAWAT DI RUMAH SAKIT UMUM SINAR HUSNI MEDAN
}

\author{
Meta Nofita*, Thomson P Nadapdap, Asriwati \\ S2 IImu Kesehatan Masyarakat, Institut Kesehatan Helvetia Medan \\ Email : metanofita1106@gmail.com
}

\begin{abstract}
ABSTRAK
Adversity Quotient perawat yang rendah akan memengaruhi pelayanan keperawatan di sebuah fasilitas kesehatan. Penelitian ini bertujuan untuk menganalisis faktor yang memengaruhi Adversity Quotient perawat di Rumah Sakit Umum Sinar Husni Medan. Jenis penelitian ini merupakan survei analitik dengan rancangan cross sectional study. Penelitian dilakukan di Rumah Sakit Umum Sinar Husni Medan. Sampel dalam penelitian ini menggunakan teknik total sampling sehingga sampel adalah seluruh perawat di Rumah Sakit Umum Sinar Husni Medan yaitu sebanyak 71 orang. Untuk menganalisis data digunakan uji chi-square dan regresi logistik. Berdasarkan hasil penelitian dapat ditarik kesimpulan bahwa ada pengaruh genetika terhadap Adversity Quotient perawat di ruang rawat inap Rumah Sakit Umum Sinar Husni Medan, ada pengaruh keyakinan terhadap Adversity Quotient perawat di Rumah Sakit Umum Sinar Husni Medan, ada pengaruh bakat terhadap Adversity Quotient perawat di Rumah Sakit Umum Sinar Husni Medan, ada pengaruh kemauan terhadap Adversity Quotient perawat di Rumah Sakit Umum Sinar Husni Medan, ada pengaruh lingkungan terhadap Adversity Quotient perawat di Rumah Sakit Umum Sinar Husni Medan, ada pengaruh karakter terhadap Adversity Quotient perawat di Rumah Sakit Umum Sinar Husni Medan. Berdasarkan hasil kesimpulan diatas maka disarankan agar rumah sakit dapat mempertimbangkan pengembangan SDM dengan memasukkan program pembinaan Adversity Quotient dalam rencana tahunan disamping pelatihan keterampilan dan pengetahuan profesi. selain itu rumah sakit juga dapat mengkaji ulang sistem rekrutmen dengan memasukkan penilaian tingkat Adversity Quotient seseorang dalam tes psikologis menjadi salah satu pertimbangan penerimaan pegawai.
\end{abstract}

\section{Kata Kunci : Genetika, Keyakinan, Bakat, Kemauan, Adversity Quotient}

\begin{abstract}
Low nurse adversity quotient will affect nursing services in a health facility. This study aims to analyze the factors that influence nurses' Adversity Quotient at Sinar Husni General Hospital, Medan. This type of research is an analytic survey with a cross sectional study design. The study was conducted at the Sinar Husni General Hospital, Medan. The sample in this study used a total sampling technique so that the sample were all nurses at Sinar Husni General Hospital, Medan, as many as 71 people. To analyze the data used the chi-square test and logistic regression. Based on the results of the study it can be concluded that there is a genetic influence on nurses' Adversity Quotient in the inpatient room of the Sinar Husni General Hospital in Medan, there is an influence of beliefs on the Adversity Quotient of nurses at the Sinar Husni General Hospital in Medan, there is an influence of talent on the Adversity Quotient of nurses at the Hospital General Sinar Husni Medan, there is an influence of willingness on nurses' Adversity Quotient at Sinar Husni General Hospital Medan, there is an environmental effect on nurses' Adversity Quotient at Sinar Husni General Hospital in Medan, there is a character effect on nurses' Adversity Quotient at Sinar Husni General Hospital, Medan. Based on the conclusions above, it is recommended that hospitals can consider developing HR by including the Adversity Quotient development program in the annual plan in addition to professional skills and knowledge training. In addition, the hospital can also review the recruitment system by including an assessment of the level of one's Adversity Quotient in a psychological test as one of the considerations of employee recruitment.
\end{abstract}

\section{Keywords: Genetics, Belief, Talent, Willingness, Adversity Quotient}

\section{PENDAHULUAN}

Manajemen rumah sakit adalah koordinasi antara berbagai sumber daya melalui proses perencanaan, pengorganisasian, dan adanya kemampuan pengendalian untuk mencapai tujuan, seperti : menyiapkan sumber daya, mengevaluasi efektifitas, mengatur pemakaian pelayanan, efisiensi dan kualitas. Dalam kegiatan organisasi rumah sakit yang kompleks pengalaman saja tidak akan cukup, 
penanganannya tidak bisa lagi atas dasar kirakira dan selera, hal ini disebabkan oleh : sumber daya yang makin sulit dan mahal, era kompetisi yang menuntut pelayanan prima, tuntutan masyarakat yang makin berkembang, manajemen profesional berarti melaksanakan manajemen dengan tata cara yang dapat dipertanggungjawabkan secara ilmiah, maka memerlukan sumber daya yang terlatih pula secara benar dan tepat.

Sumber daya manusia di sebuah Rumah Sakit perlu dikelola secara profesional, agar terwujud keseimbangan antara kebutuhan pegawai dengan tuntutan dan kemampuan organisasi. Sumber daya manusia pada sebuah organisasi mempunyai nilai yang tinggi di sebabkan oleh kemampuan yang mereka miliki dan keberhasilan suatu organisasi salah satunya ditentukan oleh kualitas sumber daya manusianya. Salah satu sumber daya manusia yang ada di Rumah Sakit adalah perawat. ${ }^{1}$

Perawat merupakan salah satu tenaga kesehatan yang memegang peranan penting dalam pelayanan kesehatan di rumah sakit. Perawat memiliki peran memberikan asuhan keperawatan yang berkualitas, karena perawat berinteraksi langsung selama 24 jam dengan pasien, dan jumlah perawat yang mendominasi sehingga perawat harus mampu memberikan pelayanan keperawatan yang bermutu. Oleh karena itu pelayanan keperawatan memiliki kontribusi yang besar dalam meningkatkan kualitas pelayanan rumah sakit melalui kepuasan pasien. $^{2}$

Berbagai dinamika yang terjadi di wilayah kerja perawat saat ini memberi pengaruh yang besar terhadap emosional perawat. Perawat sering dihadapkan dengan masalah-masalah yang terjadi di tempat kerja, seperti tuntutan pidana, ketidakmampuan berkomunikasi secara efektif dengan pasien dan tidak dapat menerima kritikan dari orang lain. Kejadian tersebut menunjukkan bahwa kecerdasan emosional perawat tergolong rendah. Pernyataan ini didukung oleh hasil penelitian Bakr dan Safaan terhadap perawat yang bekerja di Shebin El Kam University Hospital Mesir. $^{3}$

Berbagai tekanan dan masalah yang dihadapi perawat haruslah direspon dengan cara yang tepat oleh perawat itu sendiri. Perawat harus mempunyai kecerdasan untuk mengatasi masalah-masalah yang ada, jika tidak maka perawat akan berlarut-larut bahkan berujung pada tidak adanya perasaan berharga atau tidak mampu, sehingga tidak jarang membuat mereka ingin keluar dari pekerjaannya.

Berdasarkan data WHO tahun 2018 diketahui bahwa prevalensi stres kerja pada perawat bervariasi pada setiap negara di dunia. Di Negara Amerika pada tahun 2014 stres kerja pada perawat mencapai $89,2 \%$ diikuti oleh beberapa negara lain seperti Korea selatan $85,2 \%$ pada tahun 2017 , Eropa $58,2 \%$ pada tahun 2011, India $50 \%$ pada tahun 2018 dan Australia 44,82 \% pada tahun $2016 .{ }^{4}$

Berdasarkan hasil penelitian Persatuan Perawat Nasional Indonesia pada tahun 2016 menunjukkan 50,9\% perawat Indonesia pernah mengalami stres kerja, dengan gejala sering pusing, kurang ramah, merasa lelah, kurang istirahat akibat beban kerja berat serta penghasilan tidak memadai. (PPNI, 2019) Sedangkan menurut data Kementerian Kesehatan RI tahun 2019 jumlah perawat di Indonesia mencapai 462.000 orang, dengan demikian angka kejadian stres kerja pada perawat cukup besar. ${ }^{5}$

Stres kerja yang di alami oleh perawat tersebut dapat dipengaruhi oleh kecerdasan menghadapi masalah (adversity quotient). Stoltz menyebutkan bahwa Adversity Quotient adalah bentuk kecerdasan selain Intelligence Quotient (IQ) dan Emotional Quotient (EQ). Adversity Quotient yang ditujukan untuk bagaimana bertahan dan dapat mengatasi kesulitan. Maka Adversity Quotient dapat digunakan sebagai indikator bagaimana seorang melewati masa-masa sukarnya. ${ }^{6}$

Menurut Stoltz, Adversity Quotient bukanlah takdir yang tidak bisa diperbaiki secara permanen, karena Adversity Quotient adalah sebuah snapshoot dari kebiasaan respon seseorang terhadap kesulitan agar tidak mengalami stress. Dengan perbaikan tersebut maka seseorang dapat meningkatkan efektivitas untuk menghadapi setiap kesulitan yang muncul dalam kehidupannya. Tipe Adversity Quotient campers bisa berubah menjadi climbers dengan memperhatikan faktor apa yang paling dominan dan yang paling minor, kemudian melakukan modifikasi perlakuan. Adapun Faktor-faktor yang memengaruhi Adversity Quotient adalah daya saing, budaya kerja, lingkungan kerja, motivasi.

Adversity Quotient yang baik ditunjukkan oleh pemberian pelayanan kesehatan yang mampu meningkatkan laporan tingkat kepuasan pasien terhadap pelayanan keperawatan. Oleh karena itu perawat perlu menginternalisasi Adversity Quotient yang baik dalam memberikan pelayanan kepada pasien. Adversity Quotient sangat penting dalam membangun hubungan teraupetik antara perawat dengan pasien.

Adversity Quotient perawat yang rendah akan memengaruhi pelayanan keperawatan di 
sebuah fasilitas kesehatan. Pelayanan keperawatan membutuhkan perawat yang memiliki kecerdasan emosional tinggi untuk memenuhi kebutuhan pasien yang mencakup kebutuhan biologis, psikologis, sosiologis dan spiritual Perawat dengan kecerdasan emosional tinggi dapat berkontribusi untuk kinerja lebih tinggi.

Berdasarkan survei awal yang dilakukan peneliti di Rumah Sakit Sinar Husni Medan yang dilakukan terhadap 20 orang perawat, diketahui bahwa sebanyak 12 orang perawat belum mampu mengetahui emosi diri sendiri, mengatur emosi diri, 13 orang perawat tidak dapat memahami emosi orang lain. Sedangkan berdasarkan wawancara yang dilakukan dengan lima orang pasien, empat diantaranya menyatakan bahwa perawat kurang berespon ketika di tekan bel dan juga perawat sering berbicara ketus atau acuh tidak acuh terhadap pasien.

Pengamatan Adversity Quotient perawat menjadi perhatian bagi tenaga profesional keperawatan karena menjadi parameter keberhasilan dalam melakukan asuhan keperawatan yang diberikan. Keberhasilan asuhan keperawatan tidak hanya dapat meningkatkan asuhan keperawatan tetapi mutu pelayanan rumah sakit yang diberikan.

Tabel 1. Distribusi Responden di Rumah Sakit Sinar Husni Medan

\begin{tabular}{lcc}
\hline Kelompok Umur & $\mathbf{n}$ & $\%$ \\
\hline 26-35 Tahun & 37 & 52,11 \\
36-45 Tahun & 20 & 28,17 \\
46-55 Tahun & 14 & 19,72 \\
\hline Jenis Kelamin & $\mathbf{n}$ & $\%$ \\
\hline Laki-laki & 29 & 40,85 \\
Perempuan & 42 & 59,15 \\
\hline Tingkat Pendidikan & $\mathbf{n}$ & $\%$ \\
\hline D3 Kperawatan & 50 & 78,42 \\
S1 Ners & 21 & 29,58 \\
\hline Jumlah & $\mathbf{7 1}$ & $\mathbf{1 0 0}$ \\
\hline
\end{tabular}

Berdasarkan tabel 1 di atas, diketahui bahwa dari 71 responden, sebagian besar responden berumur 26-35 tahun yaitu sebanyak 37 $(52,11 \%)$ responden, sedangkan responden lainnya berumur 36-45 tahun sebanyak 20 $(28,17 \%)$, umur $46-55$ tahun sebanyak 14 $(19,72 \%)$. Dari 71 responden, sebagian besar responden berjenis kelamin perempuan yaitu sebanyak $42(59,15 \%)$ responden, sedangkan responden lainnya berjenis kelamin laki-laki sebanyak 29 (40,45\%). Dari 71 responden
Berdasarkan hal tersebut diketahui bahwa rumah sakit belum melakukan upaya untuk mengetahui faktor-faktor yang memengarui Adversity Quotient yang akan berdampak pada kinerja perawat. Penelitian ini bertujuan untuk menganalisis faktor yang memengaruhi Adversity Quotient perawat di Rumah Sakit Umum Sinar Husni Medan

\section{BAHAN DAN METODE}

Jenis penelitian ini merupakan survei analitik dengan rancangan cross sectional study. Penelitian dilakukan di Rumah Sakit Umum Sinar Husni Medan. Populasi dalam penelitian ini adalah seluruh perawat di Rumah Sakit Umum Sinar Husni Medan yaitu sebanyak 71 orang. Menurunnya jumlah kunjungan tersebut erat kaitannya dengan Pandemi Covid 19, sehingga tidak banyak pasien yang berkunjung ke rumah sakit. Sampel penelitian ada sebanyak 71 orang. Untuk menganalisis data digunakan uji chi-square dan regresi logistik.

\section{HASIL \\ Analisis Data Univariat}

Berdasarkan data yang diperoleh dari hasil penelitian dengan 71 responden dapat dilihat dalam tabel distribusi frekuensi sebagai berikut. 
Tabel 2. Analisis faktor yang memengaruhi Adversity Quotient perawat di Rumah Sakit Umum Sinar Husni Medan

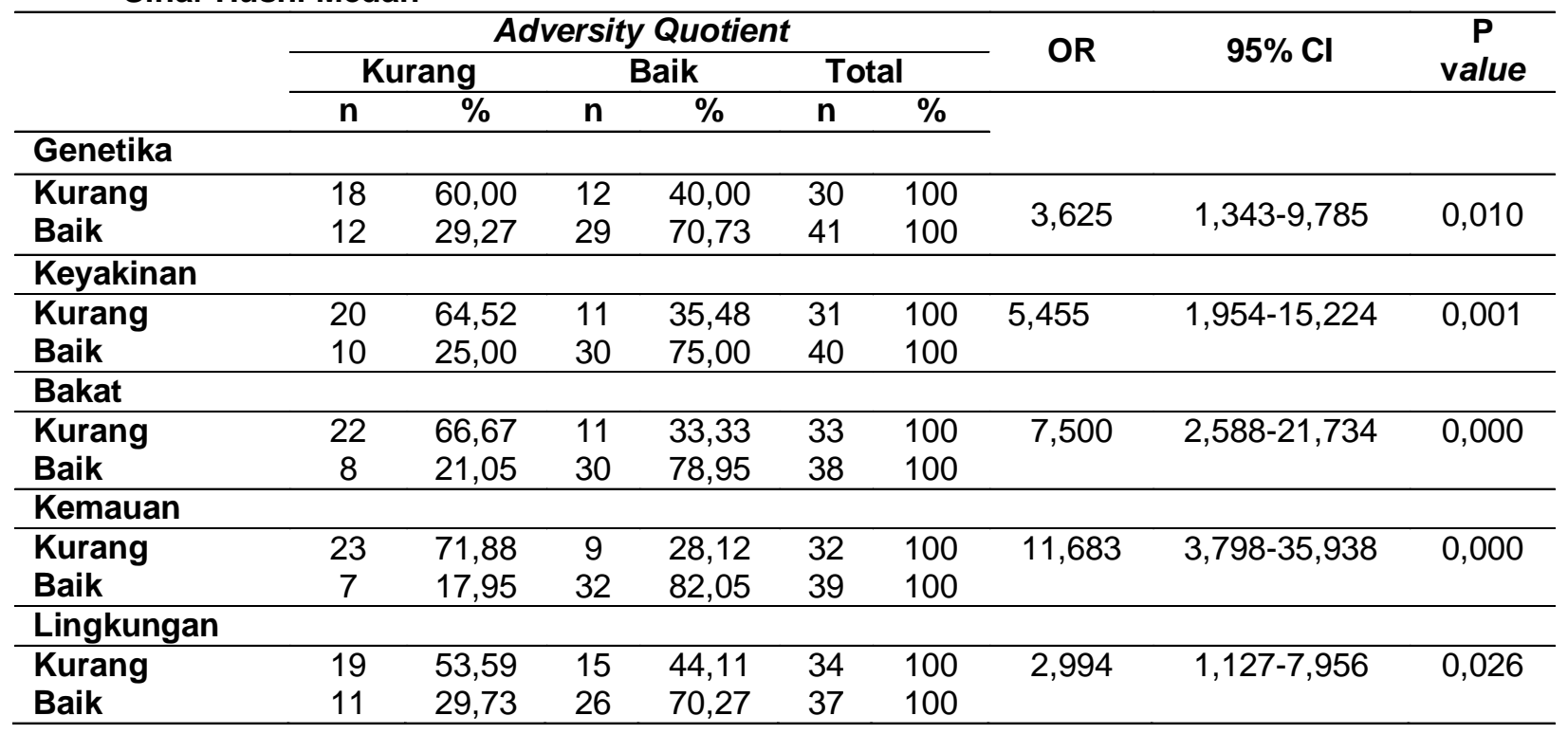

Berdasarkan tabel 2 diketahui bahwa dari 71 responden yang diteliti, sebagian besar responden memiliki genetika yang baik sebanyak $41(57,75 \%)$ responden. Dari 41 $(57,75 \%)$ responden tersebut, ada sebanyak 12 $(29,27 \%)$ responden memiliki genetika yang baik dan memiliki adversity quotient yang kurang, sebanyak $29 \quad(70,73 \%)$ memiliki genetika yang baik dan memiliki adversity quotient yang baik. Berdasarkan hasil perhitungan di atas diketahui bahwa hasil uji statistik diperoleh nilai pada baris OR yaitu $3,625$ (95\% $\mathrm{Cl}: 1,343-9,785)$ yang artinya responden yang memiliki genetika yang baik kemungkinan 3,625 kali memiliki adversity Quotient yang baik daripada responden yang memiliki genetika yang kurang. Nilai $p$ significancy yaitu $0,010<0,05$. Sehingga dapat disimpulkan bahwa ada pengaruh genetika terhadap adversity quotient perawat di Rumah Sakit Umum Sinar Husni Medan.

Dari 71 responden yang diteliti, sebagian besar responden memiliki genetika yang baik sebanyak 40 (56,34\%) responden. Dari 40 $(56,34 \%)$ responden tersebut, ada sebanyak 10 $(25,00 \%)$ responden memiliki keyakinan yang baik dan memiliki adversity quotient yang kurang, sebanyak $30 \quad(75,00 \%)$ memiliki keyakinan yang baik dan memiliki adversity quotient yang baik. Berdasarkan hasil perhitungan di atas diketahui bahwa hasil uji statistik diperoleh nilai pada baris OR yaitu $5,455 \quad(95 \% \mathrm{Cl}: 1,954-15,224$ yang artinya responden yang memiliki keyakinan yang baik kemungkinan 5,455 kali memiliki adversity
Quotient yang baik daripada responden yang memiliki keyakinan yang kurang. Nilai $p$ significancy yaitu $0,001<0,05$. Sehingga dapat disimpulkan bahwa ada pengaruh keyakinan terhadap adversity quotient perawat di Rumah Sakit Umum Sinar Husni Medan.

Dari 71 responden yang diteliti, sebagian besar responden memiliki bakat yang baik sebanyak $38(53,52 \%)$ responden. Dari 38 $(53,52 \%)$ responden tersebut, ada sebanyak 8 $(21,05 \%)$ responden memiliki bakat yang baik dan memiliki adversity quotient yang kurang, sebanyak $30(78,95 \%)$ memiliki bakat yang baik dan memiliki adversity quotient yang baik. Berdasarkan hasil perhitungan di atas diketahui bahwa hasil uji statistik diperoleh nilai pada baris OR yaitu 7,500 (95\% Cl: 2,558-21,734) yang artinya responden yang memiliki bakat yang baik kemungkinan 7,500 kali memiliki adversity Quotient yang baik daripada responden yang memiliki bakat yang kurang. Nilai $p$ significancy yaitu $0,000<0,05$. Sehingga dapat disimpulkan bahwa ada pengaruh bakat terhadap adversity quotient perawat di Rumah Sakit Umum Sinar Husni Medan.

Dari 71 responden yang diteliti, sebagian besar responden memiliki kemauan yang baik sebanyak $41 \quad(57,75 \%)$ responden. Dari 41 $(57,75 \%)$ responden tersebut, ada sebanyak 7 $(17,95 \%)$ responden memiliki kemauan yang baik dan memiliki adversity quotient yang kurang, sebanyak 32 (82,05\%) memiliki kemauan yang baik dan memiliki adversity quotient yang baik. Berdasarkan hasil 
perhitungan di atas diketahui bahwa hasil uji statistik diperoleh nilai pada baris OR yaitu 11,683 (95\%Cl: 3,798-35,938) yang artinya responden yang memiliki kemauan yang baik kemungkinan 11,683 kali memiliki adversity Quotient yang baik daripada responden yang memiliki kemauan yang kurang. Nilai $p$ significancy yaitu $0,000<0,05$. Sehingga dapat disimpulkan bahwa ada pengaruh kemauan terhadap adversity quotient perawat di Rumah Sakit Umum Sinar Husni Medan.

Dari 71 responden yang diteliti, sebagian besar responden memiliki karakter yang baik sebanyak $41(57,75 \%)$ responden. Dari 41 $(57,75 \%)$ responden tersebut, ada sebanyak 9 $(21,95 \%)$ responden memiliki karakter yang baik dan memiliki adversity quotient yang kurang, sebanyak $32 \quad(78,05 \%)$ memiliki karakter yang baik dan memiliki adversity quotient yang baik. Berdasarkan hasil perhitungan di atas diketahui bahwa hasil uji statistik diperoleh nilai pada baris OR yaitu 8,296 (95\%Cl: 2,830-24,319) yang artinya responden yang memiliki karakter yang baik kemungkinan 8,296 kali memiliki adversity Quotient yang baik daripada responden yang memiliki genetika yang kurang. Nilai $p$ significancy yaitu $0,000<0,05$. Sehingga dapat disimpulkan bahwa ada pengaruh karakter terhadap adversity quotient perawat Rumah Sakit Umum Sinar Husni Medan.

Dari 71 responden yang diteliti, sebagian besar responden memiliki lingkungan yang baik sebanyak $37(52,11 \%)$ responden. Dari 37 $(52,11 \%)$ responden tersebut, ada sebanyak 11 $(29,73 \%)$ responden memiliki lingkungan yang baik dan memiliki adversity quotient yang kurang, sebanyak $26 \quad(70,27 \%)$ memiliki lingkungan yang baik dan memiliki adversity quotient yang baik. Berdasarkan hasil perhitungan di atas diketahui bahwa hasil uji statistik diperoleh nilai pada baris OR yaitu 2,994 (95\%Cl: 1,127-7,956) yang artinya responden yang memiliki lingkungan yang baik kemungkinan 2,994 kali memiliki adversity Quotient yang baik daripada responden yang memiliki lingkungan yang kurang. Nilai $p$ significancy yaitu $0,026<0,05$. Sehingga dapat disimpulkan bahwa ada pengaruh lingkungan terhadap adversity quotient perawat di Rumah Sakit Umum Sinar Husni Medan

.Tabel 3. Hasil Tahapan Akhir Analisis Regresi Logistik

\begin{tabular}{lcccc}
\hline Variabel & B & P vlue & Exp(B)OR & 95\%Cl for Exp(B) \\
\hline Genetika & 3,259 & 0,009 & 0,038 & $0,003-0,438$ \\
Keyakinan & 2,990 & 0,017 & 0,050 & $0,004-0,584$ \\
Bakat & 0,372 & 0,004 & 0,034 & $0,003-0,349$ \\
Kemauan & 3,552 & 0,010 & 0,029 & $0,002-0,423$ \\
lingkungan & 3,603 & 0,017 & 0,027 & $0,001-0,525$ \\
\hline
\end{tabular}

Berdasarkan tabel 3 diatas dapat dilihat bahwa analisis regresi logistik menghasilkan 1 (satu) variabel yang paling dominan berpengaruh terhadap adversity quotient perawat di Rumah Sakit Umum Sinar Husni Medan dengan $p$ value $<0,05$, yaitu variabel bakat dengan signifikan 0,004 ( $\mathrm{p}$ value $<0,05$ ), OR $=0,034$ $(95 \% \mathrm{Cl}=0,003-0,349)$ artinya responden yang memiliki bakat yang baik mempunyai peluang 0,034 kali memiliki adversity quotient yang baik dibandingkan dengan responden yang memiliki bakat yang kurang dengan nilai koefisien $B$ yaitu 0,372 bernilai positif, semakin banyak responden yang meiliki bakat yang baik maka semakin banyak responden yang memiliki adversity quotient yang baik di Rumah Sakit Umum Sinar Husni Medan.

\section{PEMBAHASAN}

Genetis tidak secara langsung berperan sebagai penentu nasib seseorang. Riset-riset yang sudah pernah dilakukan dapat menjadi penjelas bahwa genetika memiliki peranan dalam pengaruh daya tahan individu. Salah satunya adalah penelitian pada ratusan anak kembar identik yang dipisahkan dan dibesrakan dilingkungan berberda namun saat dewasa masih ditemukan kemiripan-kemiripan dalam beradversity Quotient satu sama lain.

Temuan-temuan dari penelitian genetika adversity Quotient telah secara luas memengaruhi pemahaman modern tentang peran pengaruh genetik dan lingkungan terhadap adversity Quotient . Ini termasuk bukti bahwa hampir semua adversity Quotient yang diteliti berada di bawah tingkat pengaruh genetik yang signifikan, dan pengaruh itu cenderung meningkat ketika individu berkembang menjadi dewasa. Lebih lanjut, 
sebagian besar adversity Quotient manusia yang diteliti dipengaruhi oleh sejumlah besar gen dan efek individu dari gen-gen ini sangat kecil. Pengaruh lingkungan juga memainkan peran yang kuat, tetapi mereka cenderung membuat anggota keluarga lebih berbeda satu sama lain, tidak lebih serupa.

Seseorang perlu keyakinan, dengan adanya keyakinan, seseorang bisa bekerja dengan lebih baik. Seseorang bisa lebih tenang dan menguasai diri menghadapi masalah-masalah yang muncul dalam penyelesaian satu tugas. Seseorang tahu dan sadar sepenuhnya bahwa masalah itu pasti ada. Masalah itu pasti muncul. Tapi seseorang percaya bahwa seseorang mampu. Bahwa seseorang bisa untuk menyelesaikannya. Bahwa ada jalan keluar dari setiap masalah yang datang. Yang memerlukan ketenangan seseorang untuk bisa melihatnya. Dan ketenangan itu bisa didapat pada saat seseorang yakin pada diri seseorang sendiri.

Keyakinan itu diperlukan setiap saat. Tentu dalam kadar yang tepat. Terlalu yakin pada diri sendiri juga tidak baik. Dalam arti berlebihan. Karena bisa menghilangkan sikap waspada seseorang akan kemungkinan gagal. Yang pada akhirnya seseorang tidak mempersiapkan diri untuk mengantisipasi masalah yang timbul. Yang pas adalah keyakinan yang secukupnya. Seseorang tidak terlalu kuatir akan masalah yang timbul tetapi juga tidak meremehkan masalah tersebut. Seimbang. Ditengah-tengah. Sehingga seseorang tidak terbebani tugas sekaligus tidak merasa di atas angin.

Seseorang menimbulkan keyakinan dalam diri seseorang saat seseorang sudah menyelesaikan tugas tersebut, apakah seseorang bisa melihat bahwa tugas yang pada saat awal terlihat begitu menyeramkan ternyata sesederhana itu penyelesaiannya. Pada saat awal-awal ia terlihat begitu besar karena seseorang belum bisa melihat letak permasalahannya secara keseluruhan. Seseorang berada di dalamnya. Sehingga seseorang sulit untuk menemukan solusi yang tepat dari setiap permasalahan yang timbul dalam tugas tersebut. Pada saat tugas itu sudah terselesaikan, seseorang bisa melihatnya dengan lebih jelas dan lebih menyeluruh inti kesulitan dari tugas itu sebenarnya. Sekaligus dengan solusinya tentunya. Ternyata semua tidaklah serumit itu. Ternyata seseorang mampu. Ternyata seseorang bisa. Ternyata seseorang punya kapasitas untuk menyelesaikan tugas-tugas "sulit" tersebut. Setelah seseorang pernah melalui kesulitan-kesulitan dalam tugas-tugas sebelumnya. Setelah seseorang mengetahui cara-cara mengatasi kesulitan tersebut.
Setelah timbul keyakinan dan kepercaan diri, pertanyaan selanjutnya adalah bagaimana mempertahankannya? Karena keyakinan ini naik turun. Kadang seseorang merasa begitu yakinnya. Dan dilain waktu, pada saat bertemu dengan masalah yang benar-benar menguras pikiran, tenaga, dan emosi seseorang, bisa terjadi sebaliknya. Untuk mempertahankannya susah-susah gampang. Dan yang biasa terjadi, mempertahankannya lebih sulit daripada menimbulkannya. Perlu konsistensi disitu. Seseorang bisa mengulang-ulangkembali secara rutin memori tentang keberhasilan seseorang lagi dan lagi. Mengingat-ingat kembali bagaimana seseorang bisa mengatasi masalah seseorang pada saat itu. Kehadiran teman atau pun orang di seseseorangr seseorang untuk terus mengingatkan seseorang juga tidak kalah pentingnya. Bukankah semua akan terasa lebih mudah jika ada yang mendukung seseorang? Teman yang baik, teman yangmendukung seseorang. Yang selalu mengingatkan dan mengingatkan bahwa seseorang bisa. Bahwa seseorang mampu. Yang selalu membangkitkan kemauan seseorang lagi dan lagi. Tidak bosan-bosannya. Tidak ingin melihat seseorang patah kemauan untuk terus berjuang. Teman yang akan ikut sangat berbahagia dengan keberhasilan seseorang nantinya.

Kerjakan tugas-tugas seseorang, apapun itu, dengan penuh keyakinan pada diri sendiri. Dengan penuh kepercayaan pada diri seseorang sendiri. Karena dengan seseorang mendapatkan tugas tersebut, itu berarti sang pemberi tugas telah percaya pada seseorang. Pada kemampuan seseorang. Pada apa yang bisa seseorang lakukan.

Kemauan kerja mempunyai pengaruh yang besar bagi setiap para perawat dalam bekerja, jika kemauan kerja perawat tinggi maka cenderung dapat menyelesaikan pekerjaan dengan baik dan cepatserta menghasilkan produk yang berkualitas, sebaliknya jika kemauan kerja perawat rendah maka pekerjaan pun kurang terlaksana dengan baik dan lambat. Pada umumnya turunnya kemauan kerja perawat karena ketidakpuasan perawat baik secara materi maupun non materil. Pada dasarnya kemauan kerja perawat berhubungan dengan kebutuhan perawat, apabila kebutuhan perawat terpenuhi maka kemauan kerja perawat akan cenderung naik, untuk itu diperlukan usaha pemenuhan kebutuhan perawat guna meningkatkan kemauan kerja perawat.

Pentingnya kemauan kerja dapat dilihat sebagai bagian fundamental dari kegiatan manajemen sehingga sesuatu dapat ditujukan kepada pengarahan potensi dan daya manusia 
dengan jalan menimbulkan, menghidupkan, menumbuhkan tingkat keinginan yang tingga serta kebersamaan dalam menjalankan tugas perorangan maupunorganisasi. Untuk membahas tentang kemauan kerja, maka ada banyak definisi yang diungkapkan oleh para ahli tentang kemauan kerja.

Kemauan kerja atau moril adalah kesepakatan batiniah yang muncul dari dalam diri seseorang atau sekelompok orang untuk mencapai tujuan tertentu sesuai dengan mutu yang ditetapkan. ${ }^{7}$ Menurut Syukria (2004) berpendapat bahwa kemauankerja adalah suatu kondisi rohaniah atau prilaku individu tenaga kerjadan kelompok-kelompok yang menimbulkan kesenangan yang mendalam pada diri tenaga kerja untuk bekerja lebih giat dan konsekuen dalam mencapai tujuan yang di tetapkan oleh rumah sakit. ${ }^{8}$ Pendapat lain dikemukakan oleh hasibuan dimana kemauan kerjaadalah merupakan kemauan dan kesenangan yang mendalam dilakukan. ${ }^{9}$

Jadi apabila mampu meningkatkan kemauan kerja perawat maka rumah sakit akan memperoleh banyak keuntungan, pekerjaan akan lebih cepat diselesaikan, kerusakan akan dikurangi, tingkat absensi dan keterlambatan akan dapat diperkecil, kemungkinan perpindahanperawat akan dapat dikurangi dan sebagainya. Menurut pendapatpenulis kemauan kerja adalah perwujudan dari sikap seseorang dalammelakukan pekerjaan dengan kemauan dan kesenangan sehingga segalapekerjaan dapat diselesaikan dengan lebih cepat dan lebih baik.

Karakter perawat sangat sering didefinisikan sebagai sifat-sifat seperti jujur, percaya diri, kesediaan bekerja sama, tekun, empati, kemampuan untuk bekerja sesama tim, kemampuan untuk menetapkan tujuan yang realistis, dan integritas. Singkatnya, semua sifat dan adversity Quotient yang baik-baik. ${ }^{10}$

Contoh karakter yang baik dapat dilihat dari sikap seperti keinginan untuk melakukan hal yang terbaik, kapasitas intelektual seperti berpikir kritis dan alasan moral, adversity Quotient seperti jujur dan bertanggung jawab, komunikasi yang baik, memepertahankan prinsip-prinsip moral, kecakapan interpersonal dan emosional yang memungkinkan seseorang berinteraksi secara efektif dalam berbagai keadaan, dan komitmen untuk berkontribusi dengan komunita. Jadi individu yang berkarakter baik adalah seseorang yang berusaha melakukan hal yang terbaik dalam kehidupan sehari-hari dalam lingkungan pekerjaan, masyarakat dan negara.

Masyarakat membentuk karakter melalui pendidikan di pekerjaan agar memiliki karakter yang baik seperti sikap dan tingkah laku yang dikehendaki oleh masyarakat. Karena dengan sistem pendidikan yang ada di pekerjaan karakter dapat dikembangkan melalui tahap pendidikan, pengetahuan, kebiasaan hidup dengan sikap dan adversity Quotient yang baik. Namun seseorang yang memiliki pengetahuan tentang kebaikan belum tentu mampu bertindak sesuai dengan pengetahuannya tersebut apabila tidak dilatih untuk melakukan kebaikan tersebut. Dengan demikian, diperlukan komponen karakter yang baik yaitu pengetahuan tentang moral, dan perasaan tentang moral yang kemudian diaplikasikanperbuatan bermoral. Hal ini diperlukan agar peserta didik mampu memahami, merasakan, dan mengerjakan sekaligus nilai-nilai kebajikan.Perbuatan bermoral merupakan perbuatan atau tindakan moralyang berasal dari pengetahuan dan perasaan moral. Dan untuk memahami apa yang mendorong perawat dalam perbuatan yang baik maka harus dilihat tiga aspek lain dari karakter yaitu kompetensi (competence), keinginan (will), dan kebiasaan (habit). ${ }^{11}$

Pekerjaan memiliki kewenangan untuk menentukan prioritas nilai-nilai bagi pendidikan karakter, yang pada akhirnya individu perawat yang mengolah nilai-nilai itu selaras dengan pengalaman pribadinya sebagai individu yang beriman dan memiliki kehendak baik untuk hidup bersama di dalam pekerjaan dan masyarakat. Untuk itu, setiap pribadi yang terlibat dalam sebuah lembaga pendidikan yang ingin menekankan pendidikan karakter juga mesti memahami secara jernih apakah priorotas nilai yang ingin ditekankan dalam pendidikan karakter di dalam lembaga pendidikan.

Sedangkan menurut Arismantoro (2008:27) menegaskan bahwa karakter (caracter) mengacu pada serangkaian sikap (attitudes), adversity Quotient (behavior), motivasi (motivations), dan keterampilan (skills). Karakter meliputi sikap seperti keinginan untuk melakukan hal yang terbaik,adversity Quotient yang jujur dan bertanggung jawab, mempertahankan prinsip moral dan mandiri, kecakapan interpersonal dan emosional yang memungkinkan seseorang berinteraksi secara efektif dalam berbagai keadaan, dan berkomitmen dengan komunitas dan masyarakat.

Kondisi lingkungan kerja yang baik adalah salah satu faktor penunjang produktivitas perawat yang pada akhirnya berdampak pada kenaikan tingkat kinerja perawat. Kondisi ingkungan kerja dapat dibagi menjadi 2 (dua) yaitu lingkungan kerja fisik dan lingkungan kerja non-fisik. ${ }^{12}$ Contoh lingkungan kerja fisik adalah penerangan, warna dinding, sirkulasi udara, 
musik, kebersihan, dan keamanan. Sedangkan lingkungan kerja non-fisik contohnya adalah struktur tugas, desain pekerjaan, pola kerja sama, pola kepemimpinan, dan budaya organisasi.

Adanya pembagian mengenai lingkungan kerja tersebut tidak dapat dipisahkan satu sama lain. Antara keduanya harus saling seimbang, karena baik lingkungan kerja fisik maupun nonfisik sama-sama memengaruhi kinerja perawat. Untuk menyeimbangkan keduanya diperlukan kesadaran pihak manajemen dari rumah sakit tersebut. Oleh sebab itu, diperlukan lingkungan kerja yang kondusif untuk menunjang kinerja perawat dalam melaksanakan pekerjaannya, agar hasil kerja yang diperoleh dapat tercapai secara optimal.

Lingkungan kerja fisik contohnya adalah penerangan, warna dinding, sirkulasi udara, musik, kebersihan dan keamanan. Salah satu contoh rumah sakit yang mengutamakan lingkungan kerja fisik yang nyaman untuk mendukung aktivitas dan meningkatkan kinerja perawat. Hal ini yang menjadi perhatian khusus bagi para pemimpin rumah sakit untuk meningkatkan fasilitas yang ada untuk meningkatkan kinerja para perawat. Karena tempat kerja yang merupakan hal primer memberikan stimulus langsung bagi psikologi perawat dan berpengaruh terhadap kinerja yang akan memengaruhi produktivitas rumah sakit.

Suatu kondisi lingkungan kerja dikatakan baik atau sesuai apabila manusia yang berada didalamnya dapat melaksanakan kegiatannya secara optimal, sehat, aman, dan nyaman. Kesesuaian lingkungan kerja dapat berdampak dalam waktu yang lama, demikian juga dengan lingkungan kerja yang buruk akan mengakibatkan sulitnya memperoleh sistem kerja yang efektif dan efisien Ardana (2012) mengemukakan bahwa "lingkungan kerja yang aman dan sehat terbukti berpengaruh terhadap produktivitas". Selain itu dikemukakan juga bahwa "kondisi kerja yang menyenangkan dapat mencakup tempat kerja, dan fasilitasfasilitas bantu yang mempercepat penyelesaian pekerjaan". ${ }^{13}$

\section{KESIMPULAN DAN SARAN}

Berdasarkan hasil penelitian dapat ditarik kesimpulan bahwa ada pengaruh genetika terhadap Adversity Quotient perawat di ruang rawat inap Rumah Sakit Umum Sinar Husni Medan, ada pengaruh keyakinan terhadap Adversity Quotient perawat di Rumah Sakit
Umum Sinar Husni Medan, ada pengaruh bakat terhadap Adversity Quotient perawat di Rumah Sakit Umum Sinar Husni Medan, ada pengaruh kemauan terhadap Adversity Quotient perawat di Rumah Sakit Umum Sinar Husni Medan, ada pengaruh lingkungan terhadap Adversity Quotient perawat di Rumah Sakit Umum Sinar Husni Medan, ada pengaruh karakter terhadap Adversity Quotient perawat di Rumah Sakit Umum Sinar Husni Medan. Berdasarkan hasil kesimpulan diatas maka disarankan agar rumah sakit dapat mempertimbangkan pengembangan SDM dengan memasukkan program pembinaan $A Q$ dalam rencana tahunan disamping pelatihan keterampilan dan pengetahuan profesi. selain itu rumah sakit juga dapat mengkaji ulang sistem rekrutmen dengan memasukkan penilaian tingkat $A Q$ seseorang dalam tes psikologis menjadi salah satu pertimbangan penerimaan pegawai.

\section{DAFTAR PUSTAKA}

1. llyas Y. 2011. Perencanaan SDM Rumah Sakit, Teori, Metoda dan Formula Cetakan Ketiga. Depok Fakultas Kesehatan Msayarakat.

2. Nursalam N. 2014. Manajemen keperawatan: Aplikasi Dalam Praktek Keperawatan Profesional. Jakarta Salemba Medika; 2014.

3. Bakr, Manal Mohamed and Sanaa M. Safaan. 2012. Emotional Intelligence: A Key for Nurses' Performance. Journal of American Science 2012.

4. World Health Organization World. 2018. Mental Health Surveys. Jama, 291(21), 2581-2590

5. Kemenkes, R. I. 2019. Rencana strategis kementerian kesehatan tahun 2015-2019. Jakarta: Kementerian Kesehatan $R I$

6. Stoltz, PG. 2000. Adversity Quotoient, Mengubah Hambatan Menjadi Peluang(diterjemahkan oleh $T$ Hermaya). Jakarta: PT Gramedia Widiasarana Indonesia

7. Danim, Sudarwan. 2004. Motivasi Kepemimpinan \& Efektivitas Kelompok. Jakarta: PT Rineka Cipta

8. Syukria, 2004.Kontribusi Iklim Kerja Sama dan Semangat Kerjadan Semangat Kerja Terhadap kinerja Guru SMKN 1 Pinang Padang

9. Hasibuan, M.S.P. 2012. Manajemen Sumber Daya Manusia. Edisi Revisi : PT. Bumi Aksara. Jakarta 
10. Asmani, Jamal Ma'mur. 2012. Buku Panduan Internalisasi Pendidikan Karakter di Sekolah. Yogyakarta : Diva Press.

11. Arismantoro. 2008. Tinjauan Berbagai Aspek Charachter Building Bagaimana Mendidik Anak Berkarakter
?. Yogyakarta : Tiara Wacana

12. Sedarmayanti. 2001. Sumber Daya Manusiadan Produktivitas Kerja. Jakarta: Mandar Maju.

13. Ardana. 2012. Manajemen Sumber Daya Manusia. Yogyakarta : Graha IImu 